\title{
The Teacher Factor in Enhancing Quality Assurance in the Teaching/Learning of Social Studies
}

\author{
E. O. Okobia ${ }^{1}$ \\ ${ }^{1}$ Department of Educational Psychology and Curriculum Studies, Faculty of Education, University of Benin, \\ Benin City, Edo State, Nigeria \\ Correspondence: E. O. Okobia, Department of Educational Psychology and Curriculum Studies, Faculty of \\ Education, University of Benin, Benin City, Edo State, Nigeria. Tel: 234-80-2712-3037. E-mail: \\ obyokobia@yahoo.com
}

Received: June 9, 2012 Accepted: July 19, 2012 Online Published: August 30, 2012

doi: $10.5539 /$ res.v4n4p148

URL: http://dx.doi.org/10.5539/res.v4n4p148

\begin{abstract}
This paper examines quality assurance in social studies teaching. The laudable objectives of social studies in making students competent in decision making, problem solving, dealing with change and developing attitudes appropriate for effective citizenship in a pluralist democratic society, cannot be achieved without efficient and effective teaching of the subject. Therefore this paper examines the concept of quality assurance in relation to teaching and learning of social studies. It discusses the role of social studies education in Nigerian schools. It also examines how professionally trained, skilled and motivated teachers in adequate numbers in the school system can enhance quality assurance in social studies education. Finally, recommendations are made on strategies to improve opportunities for high quality teaching and learning in social studies.
\end{abstract}

Keywords: teacher factor, quality assurance, socials studies, teaching, learning

\section{Introduction}

Quality of education is now an issue of global concern. As the nation's attention is increasingly focused on the outcomes of education, policy makers have undertaken a wide range of reforms to improve schools, ranging from setting new standards and tests, to redesigning schools, new curricula and new instructional strategies. Rising expectations about what students should know and be able to do, break-through in research on how children learn, and the increasing diversity of the student population have all put significant pressure on the knowledge and skill teachers must have to achieve the ambitious goal demanded of public education. That goal is to ensure that children of all backgrounds master a demanding core curriculum and other materials that will prepare them to assume their civic and social responsibilities in a democratic society and be able to compete within the global economy. It is in the bid to achieve all these that the Federal Government of Nigeria in its wisdom decided to include social studies in the school curriculum. Specifically the only school subject which studies man in his reality and capable of addressing the issue of nation building adequately is social studies. It is meant to prepare citizens for active participation in society and help students acquire basic knowledge, positive attitudes, values and social skills needed for responsible citizenship and contributing members of the society.

The minds of the young need to be exposed to critical thinking, analysis and problem-solving strategies in a fast-changing world. In striving to achieve these goals, social studies curriculum employs a multi-disciplinary approach that takes cognizance of the socioeconomic, political, religious, physical, scientific and technological aspects of life. The teaching and learning of the subject requires a unified and comprehensive approach relying on teachers professionally trained and equipped with requisite knowledge and skills. The availability of high quality social studies teachers in adequate numbers is a sine qua non if the lofty ideals of the social studies curriculum are to be realized.

The adoption of student-centered instructional strategies including the inquiry method, discussion, role play, simulation, games and other similar strategies have been shown to enhance the active participation of students in the teaching and learning of social studies. The teacher's ingenuity in improvising, adapting and maximizing the utilization of the scarce and often insufficient instructional materials can have tremendous impact in the successful teaching and learning of social studies. 
Although some studies have reported on various aspects of the implementation of the Junior Secondary School social studies Curriculum, the literature on teacher factor in quality assurance in social studies in Nigerian schools is limited. The social studies teacher has a pivotal role in ensuring that good quality teaching and learning takes place in the social studies classroom. It is against this background that this paper examines the role of teacher in enhancing quality assurance in the teaching of social studies.

\section{Concept of Quality and Quality Assurance}

Quality can be described as standards of some thing as compared to other things that is the degree of goodness or excellence. Quality pervades every aspect of the activities undertaken in the process of education and the wide array of beneficial results of educational activities on both individual learners and the wider society. According to Maduewesi (2005), quality is a multifaceted concept, which encompasses how learning is organized and managed; what the content of learning is what level of learning to be achieved, what it leads to in terms of outcomes and what goes on in the learning environment.

Quality assurance refers to the planned and systematic actions deemed as necessary to provide adequate confidence that a product or service will satisfy given requirements for quality (Boraham \& Ziarati, 2002). Quality standards are critical and depend not only on expenditure levels but also on policy planning, implementation and monitoring. Concern about quality is uppermost in educational discourse all over the world. Generally, stakeholders are anxious to see that educational institutions deliver what they should deliver and that which they deliver produces desirable outcomes. Therefore, for an educational programme, quality assurance refers to the systematic monitoring and evaluation of the various aspects of the programme to maximize the possibility of achieving programme goals.

In a deliberate effort to ensure quality in Nigerian educational system, the Federal Government established institutions to monitor the quality of education at various levels. The Universal Basic Education Board was established for the primary and junior secondary schools, Ministry of Education for senior secondary schools, the National Commission for Colleges of Education (NCCE) for College of Education and National Universities Commission (NUC) for Universities. In 1985, the Federal Government promulgated decree No. 16 on the minimum standard for primary and secondary schools nation wide. The aims of the decree are to;

(a) Provide guidelines on general and specific principles of inspection and monitoring of schools;

(b) Provide tools for evaluating the efficiency of schools management;

(c) Guide proprietors in providing funds for their schools and

(d) Use the guidelines for accrediting the schools.

In order to put the guidelines for primary and secondary schools in operation, the National Council on Education (NCE) and the Joint Consultative Council on Education (JCCE) constituted a sub-committee in 1988 to work out the details of its operations. This committee was reconstituted in 2001. The new committee eventually formulated a 15 item guideline on minimum standards for schools nationwide. Some of the items include the minimum number of pupils per class, pupil-teacher ratio, minimum number of lesson periods per week, teaching qualification etc. The successful implementation of these guidelines requires comprehensive collaboration between the supervising institutions and the schools themselves. The role of the schools in this regard is so vital that Odijide (2007) further emphasized that the principal responsibility for ensuring quality assurance rests mainly with the educational institutions themselves.

\section{The Role of Social Studies in Nigerian Schools}

Social studies is an organized, integrated study of man and his environment both physical and social emphasizing the acquisition of cognitive, functional skills and desirable attitudes and actions for the purpose of creating an effective citizenry (Ololobou, 1989). Within the school programme, social studies provides a coordinated, systematic study of man drawing upon such disciplines as anthropology, economics, geography, history political science, philosophy, sociology and natural sciences. The primary purpose of social studies is to help young people develop the ability to make informed and reasoned decisions for public good as citizens of a culturally diverse and democratic society in an interdependent world.

Okobiah (1985) stressed that the major philosophy behind the teaching and learning of social studies in Nigerian schools is to be measured in terms of its contribution at mobilizing and enabling learners cultivate an awareness and understanding that would create the necessary basis for transforming them into effective citizens. Uche (1980) further emphasized the strategic role of social studies in nation building in his categorization of the objectives of social studies in Nigerian schools. According to him, these objectives include: (a) Providing 
humanistic education aimed at helping the child to comprehend his life, (b) Citizenship education, centered on equipping the child with skills for social responsibility, (c) Intellectual education which seeks to introduce the child to the modes of thinking and inquiry in the social sciences and (d) Value education, an area of learning that aims at inculcating in the individual some societal expected behaviors and group attitudes, values and feelings.

It was perhaps in recognition of these potentials of social studies for inculcating the right type of skills and civic virtues that the Joint Consultative Committee on Education (1982) defined the knowledge and skills embodied in social studies. These include; (1) Developing in the student the capacity to learn and to acquire basic skills including those of listening, reading, speaking, writing and calculation together with those of observation, analysis and inference which are essential for the formation of sound judgment, (2) Ensure the acquisition of the relevant body of knowledge and information which is an essential pre-requisite to personal development and to the making of positive contribution in the betterment of the society as a whole, (3) Create awareness and understanding of our physical environment and the evolving social and cultural processes, (4) Develop the ability of a rational utilization of our cultural, spiritual and natural resources and their conservation for national development, (5) Appreciate the diversity and interdependence of all members of the local and national communities and the need for cooperation for the unity of the country and international understanding, and (6) Inculcate positive attitudes and appropriate values of honesty, integrity, hardwork, fairness, justice, and togetherness for the development of the nation.

To achieve the vision of social studies, we must ensure that students become intimately acquainted with scholarship, artisanship, leadership, and citizenship. Excellence in social studies will be achieved by programs in which students acquire the knowledge, skills and attitudes necessary to understand and respect other citizens in support of common good.

\section{The Teacher Factor in Enhancing Quality Assurance in the Teaching/Learning of Social Studies}

Quality and relevant education depends a great deal on what teachers do with learners. The teacher is the central figure in any implementation of the curriculum process. The teachers must be given concerted and articulate attention if curriculum implementation efforts must be worthwhile. This section of the article examines the attributes of the social studies teachers' workforce necessary for enhancing quality assurance in the teaching and learning of the subject in the context of quantity and quality of available social studies teachers in Nigerian junior secondary schools, teachers' use of universally accepted and recommended teaching methods in social studies, teachers' use of instructional materials during social studies classroom instruction and teachers' appreciation of the emerging role of information and communication technology (ICT) in social studies teaching and learning and teachers' effective evaluation of students' learning outcomes.

\section{Availability of Good Quality Teachers}

The teacher is the central figure in the implementation of the curriculum process, therefore the teacher is the key factor in determining the quality and successes of the social studies program. The social studies program needs competent teachers who understand how to use the curriculum materials effectively. To a large extent, quality of teachers and teaching depends on the qualification, training and attitudes of the teachers. For social studies aims and objectives to be achieved, the program must be taught by qualified and committed teachers. Medley (1981) describes an effective teacher as one who plans the achievement of objectives and who executes his plans. As life changes, modern trend now emphasizes the importance of efficiency and consequently requires professionals to face their tasks effectively. This trends has resulted in new roles expected of teachers. Teachers are now required to master certain abilities, attitudes and knowledge which will enable them to cope with the contemporary problems of students. The teacher professional qualities are essential for effectiveness of the teacher in conducting the business of teaching and learning in the classroom. Stigler and Hiebert (2002) speculate that increased qualification might increase teaching effectiveness.

Performance on the job in any profession depends on several factors among which are qualification. Festermacher (1986) further states that the role of the teacher is not to make the learner, necessarily, an expert in the subject, but to make knowledge available, so that the learner can use it to become free of dogma, stereotype and convention. In order for teachers to enhance students' knowledge of social, cultural, ethical and physical worlds, teachers must have a strong command of their conceptual knowledge. They must understand not only the specialized content that they teach, but must also understand the organizing features, and the ways in which knowledge is created. Knowledgeable teachers not only have well developed conceptual knowledge, but are also students of their own teaching, and thus enable those in their custody to become students themselves. Excellent teaching requires a combination of knowledge and skills. A social studies teacher should endeavor to acquire adequate knowledge which will enable him teach any aspect of the content of social studies program. Teachers 
as specialists are expected to have good knowledge of the strategies and techniques of imparting the social studies knowledge, skills, values and attitudes suitable to age, experience and social environment of the learners.

A critical review of available literature on the subject of availability of professionally trained social studies teachers in Nigerian junior secondary schools reveal a wide gap between the curriculum recommendations and the reality on ground. Whereas the curriculum guidelines recommended a student/teacher ratio of 40:1, professionally trained junior secondary schools are lacking in most schools. A survey by Okobia (2009) in Edo State in South-South Nigeria reported only 31 professionally trained social studies teachers in 50 randomly selected public junior secondary schools with a student/teacher ratio of over 100:1. Similar findings have been reported by other investigators in different parts of Nigeria including Meziobi (2004) in South-Eastern Nigeria, Apeyuan and Aondokaa (2001) in North Central Nigeria and Garuba (2003) in North Eastern Nigeria. This deplorable state is worsened by the low status of the teaching profession and poor remuneration of teachers in Nigeria. Sometimes, salaries and other allowances are not paid regularly. To compensate for the unattractive remuneration, some teachers resort to combining teaching with various extracurricular activities such as trading within the school premises during school hours. There is also no well defined career structure for teachers in some States of Nigeria; promotions are done haphazardly and payment of accruing arrears is often ignored. This scenario makes the teaching profession unattractive to the younger generation and has contributed greatly to the inadequate number of professionally trained social studies teachers in most junior secondary schools in Nigeria.

\section{Teachers Use of Instructional Materials}

Teachers as specialists are expected to have good knowledge of the strategies and techniques of impacting the social studies knowledge, skills, values and attitudes suitable to age, experience and social environment of the learners. Instructional resources and materials, teaching resources, audiovisual aids, instructional media and instructional technology have severally been used by different investigators to denote those accessories utilized by the teacher to ensure effective teaching and learning of social studies. That these themes continue to occupy center-stage in contemporary discourse in social studies teaching and learning is not surprising. Several studies both local and international have continued to emphasize the role of instructional resources and materials in the teaching and learning process. The work of Imogie (1989), Osakwe (1993), Aduwa-Ogiegbean (1998), Jacob (1999) and Adekunle (2008) sincinctly summarized the merits of instructional resources and materials in the teaching of social studies. Aduwa-Ogiegbean (1998) noted that instructional media such as audio recordings, still pictures, slide projectors, video cassette recorders/players and film projectors offer a variety of learning experiences. As summarized by Imogie (1989) and Jacob (1999), the benefits of instructional media include: (a) promoting increased learning; (b) providing the learners the opportunities of direct interaction with the realities of their social and physical environment; (c) providing the learner with opportunities for independent and individualized learning; (d) promoting greater acquisition and longer retention of factual knowledge; (e) offering rich opportunities for students to develop communication skills while actively engaged in solving meaningful problems and (f) offering a variety of experiences which stimulates self activity on the part of the learner. As noted by Adekule (2008), transfer of learning is only possible if experience is meaningful, real and purposeful.

While modern technology has made available a lot of materials to the social studies teacher to aid him in making the subject matter more meaningful, clear and vivid in the classroom, the recurring question remains how well the social studies teacher has ingeniously adapted these resources to suit his local circumstances. The findings of Okobia's survey in South South Nigeria revealed significant lapses in the use of instructional materials in the social studies classroom. Among the surveyed classrooms, the only available and frequently used instructional materials were textbooks and chalkboards; other instructional resources including charts, graphs, diagrams, cartoons, posters, pictures, maps and atlases, though inexpensive and locally available, were sparingly used. Audiovisual and ICT resources such as televisions, overhead transparencies and computers were completely lacking. These findings corroborate the observations of Mezieobi (2004) in South East Nigeria, Jimoh (2009) in North Central Nigeria and Ogbondah (2008) in Rivers State of South South Nigeria. These studies also noted other problems associated with use of instructional materials including high cost of manufacturing and maintenance of instructional materials, reluctance of teachers to improvise, lack of social studies research rooms for storage of instructional materials and lack of skills on the part of teachers in the use of instructional materials. The findings of limited availability and poor utilization of instructional materials in schools have been corroborated by investigators both within Africa (Jotia \& Matlale, 2011; Abdo \& Semela, 2010; Ethiopia \& Kadzera, 2006) and beyond (Dahar \& Fouze, 2011) in Pakistan.

Although some of these instructional materials are expensive (Ogonor, 1992), committed teachers and students should be able to improvise materials like charts, graphs, maps, pictures, apparatus, radio, work of arts and other relevant materials where modern technology are not available. The teacher should create a condusive atmosphere 
where teaching is student-centred and democratic. In this way, students will be active and have opportunities to express their views and opinions.

\section{Teachers' Use of Recommended Instructional Methods}

Reilly (2000) provided an excellent pedagogical framework for the adoption of diverse instructional methods that promote effective learning in the social studies classroom. He noted that teachers are responsible for creating classrooms that promote effective learning as well as evolving and adopting effective instructional strategies. He emphasized five pedagogical premises that must be taken into consideration in the choice of instructional strategies in the social studies classroom: (i) learners have distinctive perspectives or frames of reference contributed to by their history, environment, interests and goals, beliefs and ways of thinking; (ii) learners have unique differences, including emotional state of mind, learning rates, learning styles, stages of development, abilities, talents and feelings of efficacy; (iii) learning is a process that occurs best when what is being learnt is relevant and meaningful to the learner and when the learner is actively engaged in creating his or her own knowledge and understanding by connecting what is being learned to prior knowledge and experiences; (iv) learning occurs best in an environment that promote positive interpersonal relationship and interactions and in which the learner feels appreciated, acknowledged and respected; (v) learning is seen as a fundamentally natural process; learners are viewed as naturally curious and basically interested in learning and mastering their world.

It was in recognition of these underlying fundamental guiding principles that the task force of the National Council for Social Studies (NCSS, 1993) emphasized the adoption of instructional strategies that take into consideration learners' background, unique differences and interests, interpersonal relationship and their natural desire to explore their surroundings and acquire new knowledge. It is within this milieu that learning becomes meaningful, integrative, value-based, challenging and exciting. Several investigators including Mezieobi (1992), Ololobou (2000) and Oganwu (2004) have catalogued the instructional strategies recommended in the National Junior Secondary Schools Social Studies Curriculum Implementation Guidelines. These interactive strategies including inquiry method, discussion, excursion, simulation games, project, problem solving, case studies, dramatization, role playing and use of resource persons create a learner-centered pedagogical process. These strategies enable the learner to take the "driver's seat" in the learning process thereby giving him/her the opportunity for knowledge discovery.

These views were re-echoed by Lemlech (2000) who in analyzing the benefits of Bruner's 1960 guided discovery as a strategy in social studies instruction identified the following benefits: (a) development and enhancement of intellectual potency, (b) arousing in the learner's intrinsic motives to learn and discover, and (c) opportunity to learn the heuristics of discovery and facilitating the conservation of memory as foremost. In addition, Lemlech (2000) added that when simulation activities are used to teach, it encourages critical thinking among students at all levels and it help to build a relationship between the school and the community. Simulation activities also allow students to form their impressions and encourage them to work for themselves on the various aspects of social life of their community. Through these exposures, the students learn to combine theory and practice of how things work by bringing real life experience into the classroom. In the same vein, Clark and Starr (2002) added that strategies like simulation and problem solving activities give high motivating values and help students develop intellectual skills inculcating in them skills of rational thinking, appreciating relationships, understanding processes and building values and attitudes. They added that the inquiry method recognized the place of culture, race, social and affective domains including academic, intellectual and cognitive aspects in the learning process and hence teachers are encouraged to use these methods.

How well the Nigerian educational system have created a fertile ground for these learner-centered instructional strategies to flourish in the social studies classroom has been an issue of contemporary discourse. Report of studies evaluating curriculum implementation demonstrates a wide gap between the expectations of the curriculum developers and the perceptions and attributes of teachers in actual classroom practice. Mezieobi's (2004) report from south east Nigeria provide a graphic picture of the substandard performance of social studies teachers in the utilization of recommended instructional methods. He reported that $70 \%$ and $80 \%$ of social studies teachers in rural and urban schools respectively, relied solely on the traditional teacher-centered expository method of instructional delivery. He noted that the activity/interactional, problem-solving and inquiry methods were rarely used in classroom instruction in both rural and urban schools. Similar observations have been reported by other investigators including Okobia (2009) and Oganwu (2004) in south south Nigeria and Ololobou (2000) in south west Nigeria.

It has been shown that adoption of activity-driven student/learner-centered techniques can have tremendous impact on student achievement in social studies. In his evaluation of the effect of teaching methods on 
achievement in social studies, Aboki (1990) studied the relative effects of guided expository methods on students' achievement in learning some selected social studies concepts. His results showed that guided discovery expository method produced significantly higher achievement scores in social studies compared with the traditional teacher-centered expository method. Similarly, Ukadike (2005) compared the effect of the traditional expository method and an experimental method (cooperative learning and learning together strategy) on students' achievement at all levels of the Junior Secondary Schools. His findings revealed that the experimental method had greater effects on students' achievement.

\section{Teachers' Use of ICT}

According to Mahabir et al (2001) educational systems around the world are under increasing pressure to use the new information and communication technologies (ICTs) to teach students the knowledge and skills they need in the $21^{\text {st }}$ century. The 1998 UNESCO World Education Report, "Teachers and Teaching in a Changing World", describes the radical implications ICTs have for conventional teaching and learning. It predicts the transformation of the teaching/learning process and the way teachers and learners gain access to knowledge and information. With the emerging new technologies, the teaching profession is evolving from an emphasis on teacher-centered, lecture-based instruction to student-centered, interactive learning environments. The teacher has a strategic role to play in harnessing these benefits of ICT in the social studies classroom. Norris, Sullivan and Poirot (2003) emphasized the importance of availability and accessibility of ICT as teachers' use of technology for curricular purposes is almost exclusively a function of their access to that technology.

It is sad to note that schools in developing countries particularly in Sub-Saharan Africa are yet to harness the benefits of ICT in social studies teaching and learning. Despite the availability of documents on policy framework, guidelines and blueprints for the integration of ICT into the classroom in various Government Ministries, the actual use of ICT in social studies classroom instruction in Junior Secondary Schools in Nigeria is still in the formative stages. In virtually all investigations from various parts of Nigeria (Mezieobi, 2004; Jimoh 2009; Okobia, 2009) none documented evidence of either availability or use of ICT tools including computers and other accessories in the teaching of social studies. The concept of the computer as a teaching tool is new to most schools and teachers. Important ICT accessories such as Internet connectivity are non-existent in most schools. Majority of the social studies teachers are not computer literate. Now and again, one observes pockets of uncoordinated efforts by the Ministries of Education and Local Education Boards in some States to arrange for quasi computer literacy training programs for teachers in the Junior Secondary Schools. These make-shift arrangements are unlikely to yield the desired results of an ICT-driven social studies classroom. There is urgent need for the educational system in sub-Saharan Africa to have a rethink and return to the drawing board. Designing and implementing successful ICT-enabled teacher education programs are the key to fundamental, wide-ranging educational reforms. Teacher education institutions must assume a leadership role in the transformation of education or be left behind in the swirl of rapid technological change. For education to reap the full benefits of ICTs in learning, it is essential that pre-and in-service teachers are able to effectively use these new tools for learning. Thus, teachers must receive adequate ongoing training, technology use must be matched to curriculum's philosophy and theory of learning, and adequate numbers of computers must be conveniently located within the classroom. Supervisory agencies working in collaboration with relevant government agencies must ensure that ICT resources including computer hardwares, software and internet facilities are available in all schools. These supervisory agencies, Teacher Education Institution (Universities, College of Education, Polytechnics, etc) and schools in developing countries must work together to harness the support and collaboration provided by international agencies including UNESCO, World Bank, Africa Development Bank, the European Union and Non-Government Organizations (NGOs) in their effort to ensure provision of ICT resources in schools. These efforts must be coordinated at various levels to ensure the smooth integration of ICT in social studies teaching and learning in the schools.

\section{Teachers' Evaluation of Students' Learning Outcome}

In social studies teaching and learning assessment of learning plays an integral role. The educational objectives are formulated keeping in view the all round development of the learners covering both scholastic and non scholastic aspects. One of the outstanding features of the Nigerian system of education is the recognition and emphasis on continuous assessment of the three domains of learning including the cognitive, affective and psychomotor. Evaluation of learning outcomes helps to ascertain the attainment of instructional objectives. Teachers need to monitor students' learning and provide them with feedback to improve their performance. In planning evaluation in social studies, teachers should use a broad range of strategies appropriately balanced to give students opportunities to demonstrate their knowledge, skills and attitudes. The evaluation of students' progress is a very complex process and good teachers build a wide repertoire of approaches in collecting 
information about students' learning. Studies of Madubuike (1985), Obemeata (1995), Mkpa (2001), Okobia (2009) revealed that evaluation in social studies is largely focused on the extent to which students retained factual content and materials. Emphasis is laid on the traditional efforts at evaluating mainly the cognitive achievements of learning. As a result, assessment of the non-cognitive learning outcomes has remained one of the neglected aspects of teaching and learning in Nigerian schools. The non-cognitive aspects of learning especially the affective domain deals with learning outcomes that promote and reinforce the learners' feelings, emotions, attitude, values, interests and appreciation.

In assessing these areas of learning, the social studies teacher is required to develop his skills of observation and bring them to full use in the classroom. Also evaluation experts have emphasized the need for classroom teachers to generate and use reliable and valid instruments in assessing non-cognitive learning outcomes. Mkpa (1987) itemized instruments including anecdotal records, rating scales and checklist for assessing non-cognitive outcomes. He noted that these techniques are effective in assessing non-cognitive outcomes because most behaviour indices of learning cannot be appropriately evaluated with paper and pencil technique.

\section{Conclusion}

In this paper, efforts have been made to provide a comprehensive evaluation of the teacher factor in enhancing quality assurance in the teaching/learning of social studies. As the world becomes more complex, educational needs continue to shift from information within each content area to teaching skills that enable students to solve complex problems across many areas. Teachers must prepare for a technology-rich future and keep up with change by adopting effective strategies that infuse lessons with appropriate technologies. Social studies is an important part of general education especially in their function in contributing to educating democratic citizens. A democratic citizen is one who is able and willing to participate in the improvement of the society. In this sense, exposure of secondary school students to social studies is especially critical because during this period, they begin to form their own values, life views and modes of living. So the challenge for social studies teaching at this level is to reach a reasonable accommodation between socialization of the youth and the development of their critical capabilities.

It is obvious that the teachers' role in ensuring quality assurance in the teaching of social studies is very paramount. The availability of professionally trained, skilled and motivated social studies teachers in adequate numbers in the junior secondary schools is the foundation in enhancing quality assurance in social studies teaching and learning. It is only through their commitment in creating a conducive learning environment that quality learning can be achieved. This involves the selection of inputs (pupils and resources) for processing in order to realize desirable /outcomes. The teachers' ingenuity in improvising, adapting and maximizing the utilization of the scarce instructional resources can have tremendous impact on the successful teaching and learning of social studies. It has also been emphasized that teachers should employ effective strategies and techniques of imparting the social studies knowledge, skills, values and attitudes suitable to age, experience and social environment of the learners. The adoption of evaluation techniques that takes cognizance of not only the cognitive domain but also the affective and psychomotor domains has been emphasized. In addition, the emerging role of information and communication technology in enhancing teaching and learning in the social studies classroom and the need for teachers to be well acquainted with these new resources was discussed.

\section{Recommendations}

For quality assurance in teaching of social studies to be achieved there is the need to have high quality teachers who are ready to impact high quality knowledge, skills, competences that are required in social studies education. The non-availability of competent professionally trained social studies teachers is a major challenge in the realization of the lofty objectives of the National Junior Secondary Schools social studies curriculum. All stakeholders involved in teacher education programs including Supervising Agencies, Federal and State Ministries of Education, Universities, Polytechnics and Colleges of Education must unite to evolve policies and programs to facilitate the training of professionally qualified and competent social studies teachers. In addition, older teachers require re-training through In-Service training programs and refresher courses. Regular seminars and workshops must be organized both at the level of "training of trainers" and at local levels to ensure that social studies teachers keep abreast with new developments in the field.

The lack of instructional materials and resources for the effective teaching of social studies in most classrooms must be addressed. The Federal and State Governments must work in close collaboration with Local and International Donor Agencies including UNESCO to evolve strategies to ensure that the required instructional resources are made available in the social studies classroom. The local School District and the Schools must explore local resources to fabricate and improvise some of the required instructional materials using local raw 
materials. In addition, the students should be actively engaged in the design and fabrication of these local instructional materials. The Federal and State Governments working with the Private Sector and Local Donor Agencies must ensure that adequate funding is made available for the provision of these resources. The current poor maintenance culture in the system must be addressed. Necessary partnerships must be established with Local and International Agencies and Institutions with the required expertise for the training of local resource persons that will be charged with the responsibility for the maintenance and safe storage of these equipments and instructional materials.

The continued over-emphasis on teacher-centered instructional strategies must be discouraged. Emphasis should be on the adoption of the universally-recommended learner-centered inquiry method of instruction. Adoption of new habits and techniques requires concerted effort on the part of both teachers and the Supervising Ministries. Refresher courses, workshops and seminars must be organized regularly to address the adoption of these new instructional techniques.

There is need for the establishment of a comprehensive and integrated system to harness the benefits of Information and Communication Technology (ICT) in the social studies classroom. This requires coordinated partnership and collaboration between the Federal and State Ministries of Education, Teacher Education Institutions including Universities, Polytechnics and Colleges of Education and Local and International Donor Agencies such as UNESCO, World Bank, African Development Bank, African Union, European Union, Economic Community of West African States and the Private Sector. Local and Regional Training Centers charged with the responsibility of training and re-training of social studies teachers in the use of ICT should be established. The necessary ICT equipments including computers, softwares and hardwares must be provided in all schools. Provision of facilities and the technical manpower required for regular maintenance and safe storage of these ICT equipments must be provided. Other important accessories including regular power supply must be made readily available. The provision of these ICT resources requires adequate funding and the Federal, State and Local Governments must rise to their responsibilities in this direction.

\section{References}

Adekule, M. O. (2008). Methods and resources in teaching social studies. Retrieved April 10, 2008, from http://www.ijeunilorin.net/alphabeticlist.php

Apeyuan, K. D., \& Anondokaa, M. A. (2001). Enhancing performance by a conductive work. Nigeria, 1(1), 73.

Borahan, N. G., \& Ziarati, R. (2002). Developing quality criteria for application in higher education sector in Turkey. Total Quality Management, 13(7), 913-920.

Clark, S. A., \& Starr, G. S. (2002). Methods of teaching in middle school and high schools. Boston: Harper.

Federal Republic of Nigeria. (2004). National Policy on Education. Lagos NERDC.

Fester, M. G. D. (1986). Philosophy of research on teaching. In M. C. Wittrock (Ed.), Handbook of research and teaching (3rd ed.). New York: Macmillan.

Garuba, A. (2003). Teachers and teaching in Nigeria. A paper presented in $11^{\text {th }}$ biennial conference of international study association for teachers and teaching (ISATT), Leiden, Netherland. Retrieved June 2006, from http://www.isatt.org

Garuba, A. (2003). Teachers and teaching in Nigeria. A paper presented in $11^{\text {th }}$ Biennial Conference of International Study Association for Teachers and Teaching (ISATT), Leiden Netherlands. Retrieved August 2010, from http:// www.isatt.org

Imogie, A. I. (1989). Will N10 do? An example of how lack of fund can kill improvisation of educational materials in secondary schools in Nigeria. Journal of the Nigerian Association for educational media and technology, 2(2), 144-145.

Lemleck, J. K. (2000). Curriculum and instructional methods for elementary school. New York: Macmillan Publishing Company.

Medley, D. (1981). Assessing teacher performance from observed competency indicators defined in class teachers. Journal of educational research, 74(4), 197-216.

Meizieobi, K. A. (1992). Theme in Social Studies education in Nigeria. Owerri: Whyte and Whyte Publishers.

Mezieobi, K. A. (2004). Evaluation of the implementation of the junior secondary school social studies curriculum in Abia State. Unpublished Ph.D thesis. Delta State University, Abraka, Nigeria. 
Mkpa, M. A. (2001). Misconceptions and conceptions of social studies. In C. Ofuebe (Ed.), Dynamic of social studies. Enugu: New Generation Books.

NCSS. (1993). Standard for teaching and learning in the Social Studies. Washington DC: National Council for the Social Studies.

Odejide, A. I. (2007). Quality and Relevance in University of Ibadan's General Studies Programme: A public lecture to commemorate the general studies programme's twenty-first anniversary of University of Ibadan, Nigeria.

Oganwu, P. (2004). The effectiveness of guided discussion, problem solving, inquiry and expository lecturer strategies on social concept attainment. Unpublished Ph.d thesis Delta State University (DELSU) Abraka.

Ogonor, B. O. (1992). Methods of teaching social studies in primary schools. In M. A. Izuagie (Ed.), Subject teaching methods NCE series. College of Education, Benin City.

Okobia, E. O. (2009). An Assessment of the implementation of the junior secondary school social studies curriculum in Edo State unpublished Ph.D thesis. University of Benin, Benin City, Nigeria.

Ololobou, Y. P. S. (1989). Social Studies: The search for a definition. Nigeria journal of Social Studies, 1(1\&2), 22.

Ololobou, Y. P. S. et al. (1999). Dimensions of social studies. Pankshin, Academic trust fund.

Osakwe, E., \& Itedjere, P. (1993). Social Studies for tertiary students in Nigeria. Enugu: New Age Publishers.

Reilly, D. H. (2000). The learner centered high school prescription for adolescent success in education. Winter, 121(2), 219.

Stigler, E. W., \& Hiebert, J. (2002). The teachers gap, Best ideas from the world's teachers for improving education in the classroom sample of school. The research bulletin No. 11. 